\title{
Cyber Culture through Social Media Instagram on Fisip Unswagati Students
}

\author{
Nurudin $^{1}$, Farida Nurfalah ${ }^{2}$, and Abdul Jalil ${ }^{3}$ \\ \{Imammahdi264@gmail.com ${ }^{1}$, faridan774@gmail.com² , abdjaltea@yahoo.com ${ }^{3}$ \} \\ Faculty of Social Science and Political Science, Gunung Jati Cirebon Swadaya University, Indonesia ${ }^{1,2,3}$
}

\begin{abstract}
Currently physical communication is not only done, but nowadays it can be done by using media. Communication can occur for users of messages and sentences by others to complete the interaction of messages about the user to be appreciated and received responses from others. Any message anywhere to view photos or photos. The purpose of this study is; ; 1 . To find out how is Siber's Culture Student of Faculty of Social and Political Sciences Unswagati, 2. To find out how is the self-reflection of Unswagati Students interpreted as fellow Instagram users, 3. To find out how does the interaction change with the presence of Instagram media. This study used descriptive study and used five informants. Selection of informants by using purposive. The result 1). Instagram social media is generally used by individuals to upload photos or videos; 2 . The student that Instagram can reflection on Fisip Unswagati Student in the perception of student participation within reasonable limits and interaction with fellow users is perceived as reasonable; 3). Shifting interaction with Instagram media presence, that is, following the times, easy to reach and there are no limits.
\end{abstract}

Keywords: Cyber Culture, Media, Instagram

\section{Introduction}

The presence of information and communication technology opens up space for human life more broadly and increasingly without limits, one of which is communication technology innovation in the form of social media such as Instagram. The other people have the potential to ourselves and at least assume what others assume about us [1]. In the past, humans interacted with face to face or writing letters by consuming a long time, but gradually displaced by communication technologies such as cell phones (cellphones), computers, the internet and social media. The existence of information and communication technology makes human interaction in this world faster, broader and easier.Today's social media users are increasingly increasing and expanding, as reported by the Ministry of Communication and Information (Kemenkominfo) that internet users in Indonesia reach 63 million people. Of these 95 percent they use the internet to access social networks or what we often refer to as social media. If we observe not only among teenagers who utilize social media, even among adults there are many who use social media [2].

Cyber culture or cyberculture departs from the phenomenon that appears in cyberspace and cyber media. Culture is basically the values that arise from the process of interaction between individuals, in this context that is the experience of individuals and or between individuals in 
using and relating to the media. These values are recognized, both directly and indirectly, along with the time spent in these interactions [3].

Social media is a favorite to interact for each individual, making it easier for humans to express feelings, desires and so on. Social media also helps people understand the world easily, find out more quickly about information and developments in the world. The presence of social networking sites (social networking sites) or often referred to as social media like Instagram is a medium used to publish content, such as profiles, activities or even opinions of users, as well as media that provides space for communication and interaction in social networks in cyberspace [3].

Therefore, the writer is interested in conducting research; 1. How is Siber's Culture Student of Faculty of Social and Political Sciences Unswagati ?, 2. How is the self-reflection of Unswagati Students interpreted as fellow Instagram users?, 3. How does the interaction change with the presence of Instagram media?

\section{Method}

The approach used in this study is a qualitative approach is more holistic, inductive and naturalistic, whereas the type of study is a type of descriptive-qualitative, researchers used indepth interviews to the object under study and observation, so that the accuracy of the information obtained is more accurate. One reason for using a qualitative approach is that this method can be used to discover what is hidden behind the phenomena which sometimes is something that is difficult to understand rationally. Through this qualitative approach, an opportunity to better understand the phenomenon under study by the consideration that life is always changing and dynamic human behavior [4].

\section{Result}

\subsection{Siber Culture Unswagati Faculty of Social Sciences Students}

Instagram social media is generally used by individuals to upload photos or videos. Features that recently appeared are the insta story or snapshot and instalive (live video) features. In addition, by having a lot of followers (followers) on Instagram social media, users can be increasingly known by public netizens and even users will get endorsement offers or other jobs. Table 1 explains the profile of informants.

Table.1 Profile of Informants

\begin{tabular}{llll}
\hline No & $\begin{array}{l}\text { Fisip Students } \\
\text { Instagram account }\end{array}$ & Gender & Education \\
\hline 1 & @its.. & Man & Non Semester \\
2 & Mau.. & Man & 6th Semester \\
3 & @Zae.. & Man & 6th Semester \\
4 & @ali.. & Women & 6th Semester \\
5 & @es.. & Women & 6th Semester \\
6 & @nov.. & Women & 6th Semester \\
\hline
\end{tabular}


1, 2, and 3 informants for Instagram, they want to be recognized for their existence, add insight, establish friendships, interact with new people, add relationships, exchange information, blaspheme netizens, like baper while informants 4, 5 and 6 Yes, because they want many friends, want to be recognized by active students Benefits of Instagram social media add insight, establish friendships, interact with new people, add relationships, and can upload photos for followers to know, Comment and Direct messages. When they use Instagram, the majority of female informants think they used to think first before uploading photos because "to look cute"; "Edited first to look beautiful to look at"; and "to make it look more different", while male informants are more natural as they are: "photos are not edited as they are".

Besides liking unpaod photos via Instagram, there will be some things they don't like:

Men : 1. Men most like Instagram users upload photos and instastory, so it looks more different.

2. Men at least like spam photos and upload too much

Women: 1. Women most like users of Instagram upload photos, culinary, traveling, Kpop, etc. 2. Women who are least liked by spam photos and hater comments

\subsection{Self-reflection Unswagati Students are interpreted as Fellow Instagram users}

Every time we upload a photo there must be someone who sees a photo, likes our photos and even comments. According to the informant they tend to ask the opinions of others from uploading to get comments from nearby such as boyfriends, mamah (parents) who are more concerned. Your reaction to photos and videos uploaded by friends on Instagram always responds with likes or comments in the hope of motivating other friends, becoming a lot of acquaintances, lots of information, even for business promotion through DM, so that activities carried out by commenting on each other, follow each other, support and support each other. student that Instagram can reflection on Fisip Unswagati Student in the perception of Student Participation within reasonable limits and interaction with fellow users is perceived as reasonable

\subsection{Shifting Interaction with Instagram Media Presence}

Shifting interaction with the presence of instagram media shifts interaction with the presence of instagram media because it is based on interviews with informants, namely following the times, easy to reach and there are no limits. Besides that, there are also lots of pictures, photos of both personal and other people can be seen including the artist. Informants choose Instagram social media because IG is the most popular social media, IG is easy to post, including video and photo features are very good and interesting. At the time of posting on Instagram the informants mostly appeared as they were about everyday life.

\section{Conclusion}

Cyber Culture Fisip Unswagati students have many followers, Instagram social media is generally used by individuals to upload photos or videos. users can be increasingly known by public netizens even users will get endorsement offers or other jobs. Self-reflection Unswagati students are interpreted as fellow users of Instagram, student that Instagram can reflection on Fisip Unswagati Student in the perception of Student Participation within reasonable limits and 
interaction with fellow users is perceived as reasonable. Shifting interaction with Instagram media presence, that is, following the times, easy to reach and there are no limits.

Acknowledgements. The authors would like to thank the reviewers, especially to Universitas Muhammadiyah Sidoarjo (UMSIDA) that hold the International Conference on Emerging Media, and Social Science (ICEMSS) on December 7-8, 2018 Banyuwangi, Indonesia.

\section{References}

[1] E. Putri R, "Representasi Identitas dan Masyarakat Tontonan ," Journal Pemikiran Sodiologi, vol. 3 , no. $1,2016$.

[2] Kominfo : Pengguna Internet di Indonesia, https://kominfo.go.id/index.php/content/detail/3415/Kominfo+\%3A+Pengguna+Intern et+di+Indon esia+63+Juta+Orang/0/berita_satker, accessed on June 18, 2018), 2013.

[3] R. Nasrullah, "Media Sosial: Perspektif Komunikasi, Budaya, dan Sosioteknologi, Bandung: Simbiosa Rekatama Media , 2017.

[4] J. Rakhmat. "Metode Penelitian Komunikasi," Bandung: Remaja Rosdakarya, 2000. 